\title{
Conceptual Design and Performance Analysis of an Exhaust Gas Waste Heat Recovery System for a 10000TEU Container Ship
}

\author{
Zheshu Ma, Prof. \\ Dong Yang, M. Sc. \\ Qiang Guo, M. Sc. \\ Jiangsu University of Science and Technology, Zhenjiang, P.R. China
}

\begin{abstract}
According to operation characteristics of the main engine 9K98ME-C7, a combined turbines-exhaust gas waste heat recovery system is proposed to recover waste heat and increase system energy efficiency. Thermodynamic models based on the first thermodynamic law and the second thermodynamic law are formulated. The superheated steam yield, the total electric power yield, the first thermodynamic law efficiency, the exergy efficiency at different exhaust gas boiler working pressure, and the variation of the exergy efficiency under different feed water temperature and different steam turbine back pressure are analyzed. Thermodynamic results indicate that the most appropriate exhaust gas boiler pressure is $0.8 \mathrm{MPa}$ for studied main engine and the total thermal efficiency with combined turbines arrangement has climbed up to $53.8 \%$ from $48.5 \%$.
\end{abstract}

Keywords: exergy efficiency; marine diesel engine; thermal efficiency; waste heat recovery system

\section{INTRODUCTION}

Main engines on large or ultra-large merchant ships are very powerful and consume large amount of fuel oil. A slight increase of their thermal efficiency could bring round-sum benefit for ship owners. Meanwhile, with the rising fuel costs and global warming ongoing, energy-saving and emissionreduction have been getting more and more highlighted. Based on this consideration, Waste Heat Recovery systems (WHRs) are considered to furnish newly-designed ships and refurnish in-service ships. Thermal efficiency of state-of-the-art high performance marine diesel engines achieves nearly $45 \% \sim 55 \%$, and waste heat sources on ships are mainly resided in exhaust gases and outlet cooling water, taking away $25 \% \sim 35 \%$ and $20 \% \sim 25 \%$ of energy in fuel, respectively. These two waste heat sources are also the most potential candidates onboard to be recovered to increase the total thermal efficiency.

Conventional waste heat recovery systems onboard are cogeneration systems, i.e. combined heat and power generation systems, and usually use water as working fluid in Rankine Cycles (RCs) [1-5]. When analyzing these systems based on thermodynamic laws, effects of pinch point are always paid much attention. C.J Butcher and B.V. Reddy [6] analyzed effects of different specific heat models, gas inlet temperature and other operating parameters on entropy generation rate and the second thermodynamic law efficiency for a waste heat recovery based power generation system. They found that, approximating the exhaust gas as standard air led to either underestimation or overestimation of power plant performance on both first thermodynamic law and second thermodynamic law point of view. Actual gas composition models and specific heat models should be used to predict second thermodynamic law performance more accurately.

Compared with conventional waste heat recovery systems onboard, Organic Rankine Cycles(ORC) employ organic working fluid in steam power cycles. ORCs possess several notable advantages for economical utilization of energy resources, small system applications and environmental impacts and can give better performance to recover low grade waste heat onboard [7]. Yalcin Durmusoglu et al.[8] designed an ORC cogeneration system for a container ship and employed three performance criterions, i.e. energy utilization factor, artificial thermal efficiency and exergy efficiency, to evaluate system performance. Thermodynamic results indicated that ORC cogeneration systems could recover more low grade waste heat onboard than conventional RC cogeneration systems.

Ships are always the most efficient transportation means when important environment aspects are taken into account $[9,10]$. Ships normally have enough waste heat (both energy quantity and energy quality) potential to be ultilized and cover almost all demands for thermal energy onboard. Cogeneration systems adapt to large and ultra-large ships. However, for small ships and other waste heat sources, Thermoelectric Generators (TEGs) represents a promising solution direction. N.R Kristiansen et al. [11] analyzed the waste heat sources on a median size bulker ship equipping a main engine of $7.8 \mathrm{MW}$ 
and found that incinerators were most promising application for TEGs. Moreover, important factors for successful TEGs applications were commercialization of materials research and reduced price/Watt power output TEGs can bring[12].

In comparison with exhaust gases, it is more difficult to recover waste heat of cooling water from cylinder liner in marine diesel engines due to its low waste heat grade. Liu Shi-Jie et al.[13] designed a high temperature heat pump waste heat recovery system to recover waste heat of cooling water from cylinder liner and recommended that R123 and R245fa be the appropriate working fluids. Such system could generate enough saturated vapor (saturated temperature $120^{\circ}$ ) to meet thermal energy requirements onboard.

In available literatures, the minimum value of exhaust gas boiler working pressure for different types of ships, $0.7 \mathrm{MPa}$, was normally selected to calculate advantages of waste heat recovery systems. Optimal working pressure of exhaust gas boiler is seldom analyzed when installing a waste heat recovery system designed for a given ship. Superheated steam yield, total electric power yield, first law efficiency, second law efficiency at different exhaust gas boiler working pressure are seldom analyzed. As well, effects of feed water temperature and steam turbine back pressure on system exergy efficiency are seldom studied. In this paper, a WHRS is proposed to recover waste heat of main engine 9K98ME-C7. Superheated steam yield, total electric power yield, first law efficiency, second law efficiency at different exhaust gas boiler working pressure are thermodynamically analyzed. In addition, exergy efficiency is modeled under different feed water temperature and steam turbine back pressure. For a better understanding of such WHR solution, a conparison to results in published literatures are also done.

\section{PROBLEM}

Waste heat in exhaust gas and cooling water are the two main heat sources to be exploited on ships. Exhaust gas is always chosen due to its high temperature and huge mass flow rate. In order to effectively recover thermal energy in exhaust gas, exhaust gas temperature is usually increased [2] by an exhaust gas bypass system which could increase exhaust gas temperature by approximately $50^{\circ}$ and specific fuel oil consumption (SFOC) slightly by about $2 \mathrm{~g} /(\mathrm{kW} \cdot \mathrm{h})$.

When choosing waste heat recovery systems, payback time, electricity yield, system size, maintenance cost should be taken into account since waste heat recovery systems are rather expensive and appropriate only for large merchant ships. MAN B\&W Diesel recommends single-pressure steam turbine system when installing combined turbines [2].

Currently, there are three different types of exhaust gas waste heat recovery systems. (1) Power Turbine Generator (PTG). PTG system is small, simple and can produce power approximately $4 \%$ of the main engine Specified Maximum Continuous Rating (SMCR). The exhaust gas expands in the power turbine while its temperature decreases. The enthalpy drop of the exhaust gas transforms into turbine's kinetic energy. The generator connects to the turbine via a gearbox. PTG system has been applied on some container ships and LNG ships [14]. (2) Steam Turbine Generator (STG). STG system is relatively complicated and can produce power equivalent to approximately $5 \%$ to $7 \%$ of the main engine SMCR. Steam turbine is driven by superheated steam. Steam is produced by a large exhaust gas boiler installed on the main engine exhaust gas piping system. The enthalpy drop of the superheated steam transforms into turbine's kinetic energy. The generator connects to the turbine via a gearbox. (3) Combined Turbines. Combined Turbines system is a combination of the above two systems. The power turbine is connected to the steam turbine via a gearbox and the steam turbine is further connected to a large generator, which absorbs the power from both turbines. Such system is most complicated and can produce power equivalent to approximately $10 \%$ of the main engine SMCR.

For main engine 9K98ME-C7, Combined Turbines system is the most appropriate to be employed onboard. For a better management, the boiler is of single-pressure type and the steam turbine is of multi-stage single-pressure condensing type. The system diagram is shown in Fig. 1 (without shaft generator/ motor). The exhaust gas boiler system diagram is shown in Fig. 2. The mass flow rate profile and temperature profile of the exhaust gas after turbochargers are shown in Fig. 3 and in

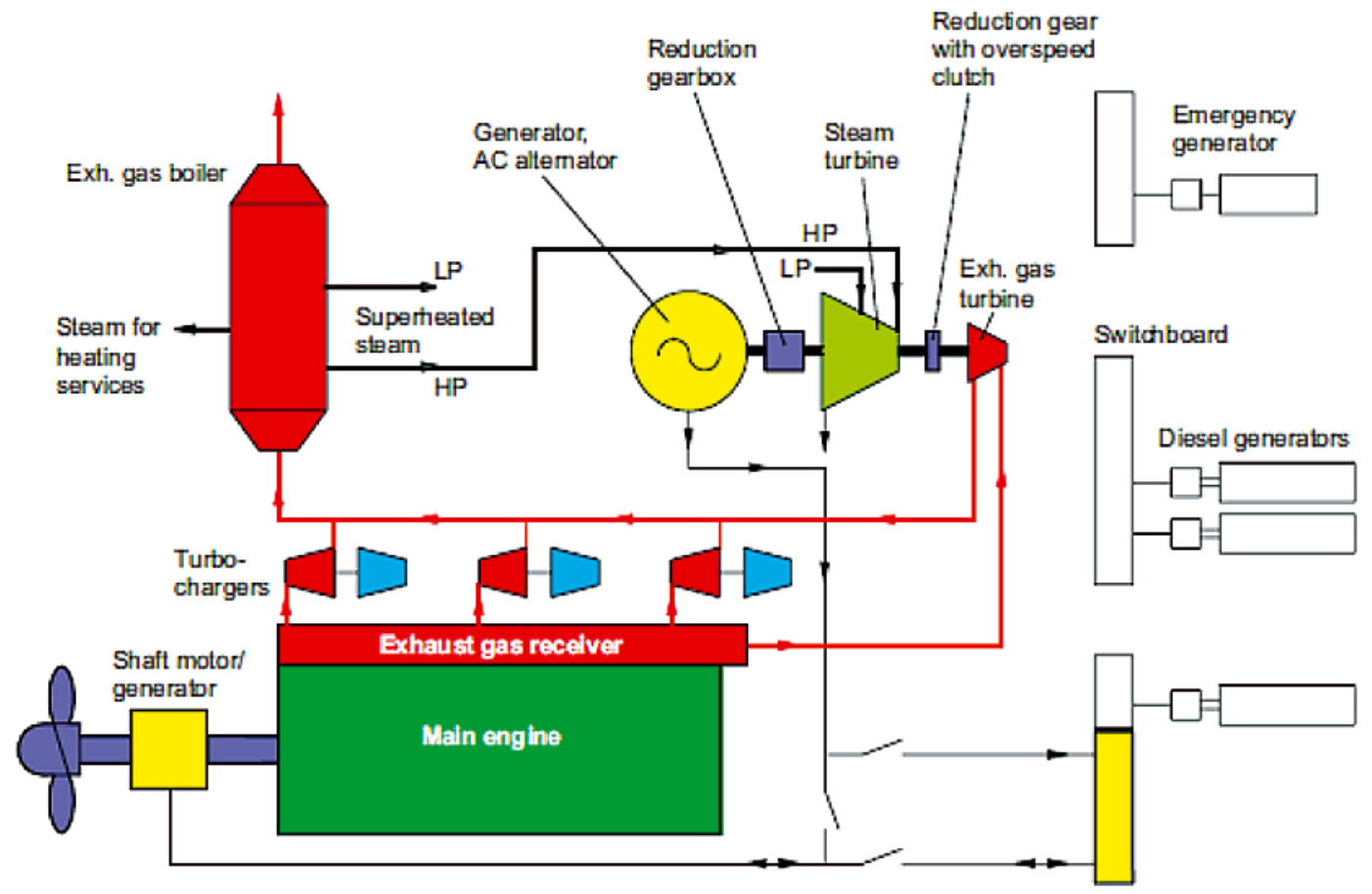

Fig. 1. Combined Turbines system diagram (without shaft motor/generator) for main engine 9K98ME-C7 with the boiler of single-pressure type and the steam turbine of multi-stage single-pressure condensing type 
Fig. 4, respectively. The exhaust gas bypass valve will be open with engine loads higher than about 50\% SMCR, mass flow rate of exhaust gas reduces and temperature increases. When engine loads are lower than 50\% SMCR, the exhaust gas bypass valve will be closed for a normal operation of the boiler. In this case, the temperature decreases obviously and the mass flow rate increases slightly.

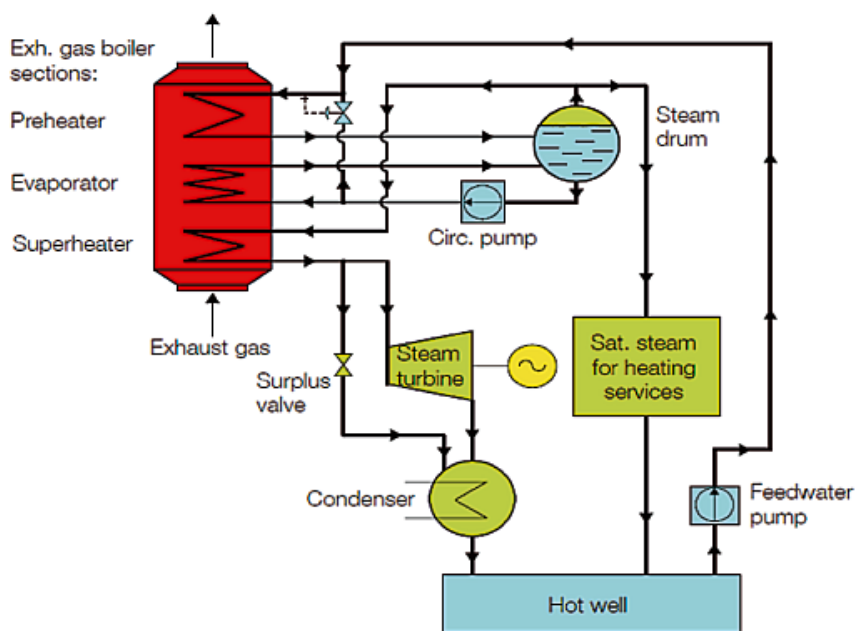

Fig. 2. The single-pressure type exhaust gas boiler system diagram of Combined Turbines system (without shaft motor/generator) for main engine $9 K 98 \mathrm{ME}-\mathrm{C} 7$ with the steam turbine of multi-stage single-pressure condensing type

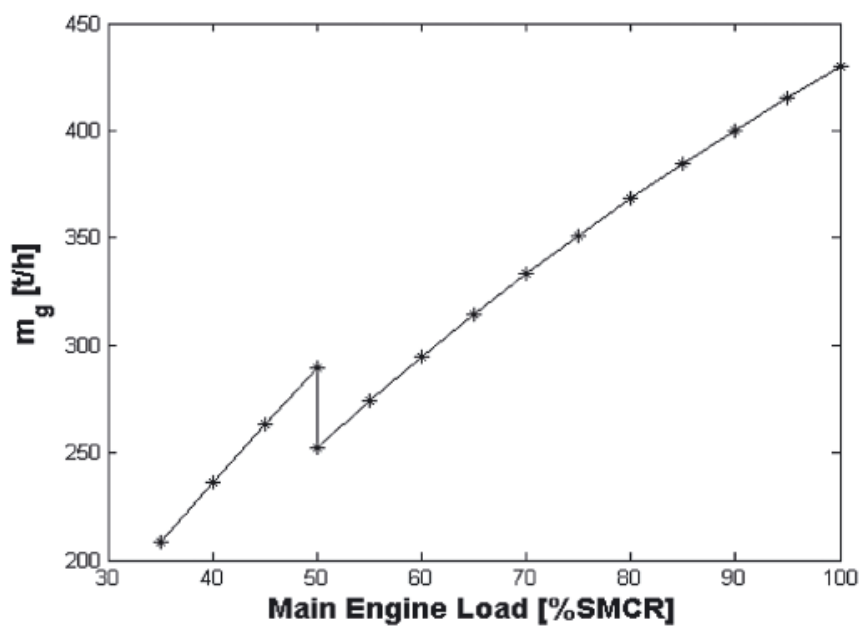

Fig. 3. The variation of exhaust gas mass flow rate after turbochargers with main engine loads for main engine $9 K 98 M E-C 7$ with Combined Turbines

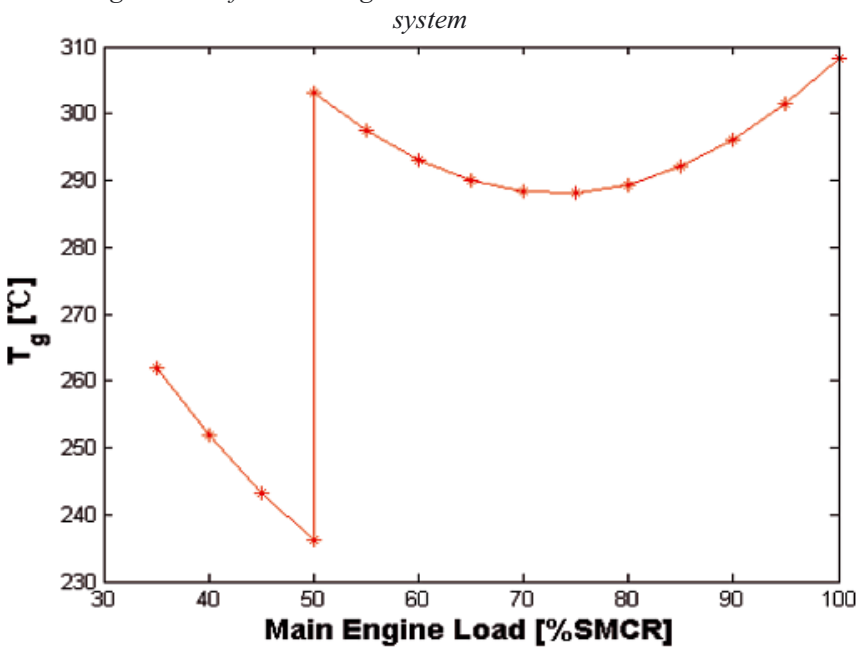

Fig. 4. The variation of exhaust gas temperature after turbochargers with main engine loads for main engine $9 K 98 \mathrm{ME}-\mathrm{C} 7$ with Combined Turbines system

\section{FORMULAE}

Typical temperature profiles of exhaust gas and steam/water in the exhaust gas boiler are shown in Fig. 5. The exhaust gas enters the superheater at $\mathbf{T}_{\mathrm{g} 1}$ where the saturated steam is superheated to high temperature $\mathbf{T}_{\mathrm{sh}}$. The exhaust gas then enters the evaporator at $\mathbf{T}_{\mathrm{g} 2}$ where a mixture of saturated water and saturated steam exists. The exhaust gas leaves the evaporator at $\mathbf{T}_{\mathrm{g} 3}$ and the pinch point $\left(\mathbf{T}_{\mathrm{PP}}\right)$ means the temperature difference between $\mathbf{T}_{\mathbf{g} 3}$ and the saturated temperature $\mathbf{T}_{\mathrm{sat}}$. The exhaust gas then enters the preheater at $\mathbf{T}_{\mathrm{g} 3}$ where the water is preheated. The exhaust gas is discharged to the environment at $\mathbf{T}_{\mathbf{g} 4}$.

Following assumptions are made in the analysis [15]:

- steam is at steady state;

- no pressure drops on steam side;

- pressure drop on exhaust gas side does not affect its temperature;

- approach point is negligible;

- the expansion process in the steam turbine is an isentropic expansion process;

- the specific enthalpy of the superheated steam entering the steam turbine is equal to the specific enthalpy of the superheated steam left the superheater.

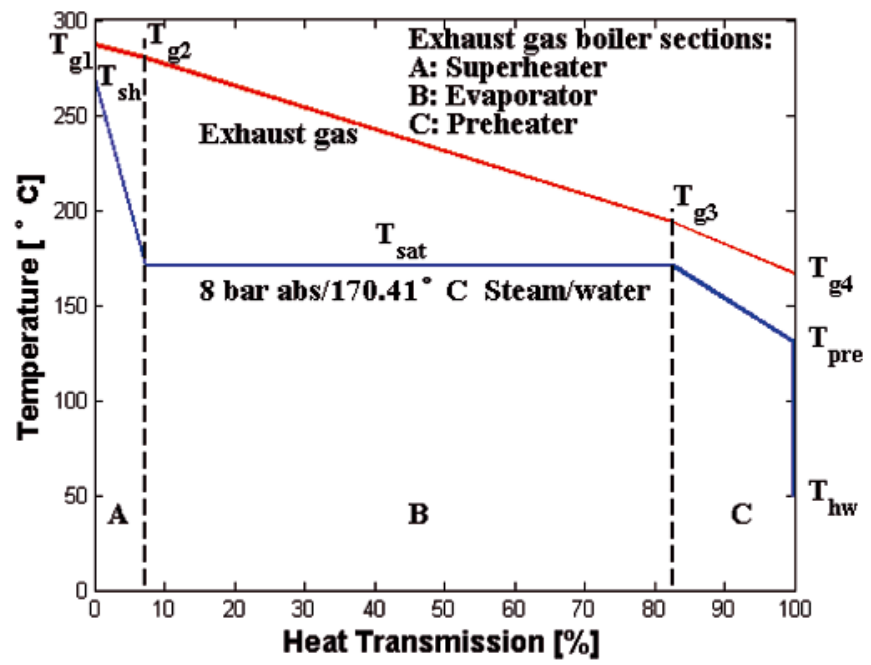

Fig. 5. Typical temperature profiles of exhaust gas and steam/water in the exhaust gas boiler for main engine with Combined Turbines system

\section{Formulae of Preheater}

By mixing the water from họt well $\left(\dot{\mathbf{m}}_{\mathrm{hw}}\right)$ and a part of saturated water from the boiler $\left(\dot{\mathbf{m}}_{\mathbf{B} 1}\right)$, the water with a mass flow rate $\dot{m}$ could enter the preheater at $\mathbf{T}_{\text {pre }}\left(130^{\circ}\right)$. The mass flow rate $\dot{m}$ can be expressed as:

$$
\dot{\mathrm{m}}=\dot{\mathrm{m}}_{\mathrm{hw}}+\dot{\mathrm{m}}_{\mathrm{B} 1}
$$

According to the law of energy conservation, there will be:

$$
\dot{\mathrm{m}} \times \mathrm{h}_{\text {pre }}=\dot{\mathrm{m}}_{\mathrm{hw}} \times \mathrm{h}_{\mathrm{hw}}+\dot{\mathrm{m}}_{\mathrm{B} 1} \times \mathrm{h}_{\text {sat }}^{\prime}
$$

where:

$h_{h w}-$ the enthalpy of feed water, $[\mathrm{kJ} / \mathrm{kg}]$,

$h_{\text {sat }}^{\prime}$ - the enthalpy of saturated water at specific exhaust gas boiler working pressure, $[\mathrm{kJ} / \mathrm{kg}]$,

$\mathrm{h}_{\text {pre }}$ - the enthalpy of water $\left(130^{\circ}\right)$ entering the boiler, $[\mathrm{kJ} / \mathrm{kg}]$.

Therefore, the saturated water from the boiler $\dot{\mathrm{m}}_{\mathrm{B} 1}$ will be:

$$
\dot{\mathrm{m}}_{\mathrm{B} 1}=\dot{\mathrm{m}}_{\mathrm{hw}} \times \frac{\mathrm{h}_{\mathrm{pre}}-\mathrm{h}_{\mathrm{hw}}}{\mathrm{h}_{\mathrm{sat}}^{\prime}-\mathrm{h}_{\mathrm{pre}}}
$$


Using the temperature profiles, one can reach:

$$
\begin{aligned}
& \left(\dot{\mathrm{m}}_{\mathrm{hw}}+\dot{\mathrm{m}}_{\mathrm{B} 1}\right) \times\left(\mathrm{h}_{\mathrm{sat}}-\mathrm{h}_{\mathrm{pre}}\right)= \\
= & \mathrm{C}_{\mathrm{g}} \times \dot{\mathrm{m}}_{\mathrm{g}} \times\left(\mathrm{T}_{\mathrm{g} 3}-\mathrm{T}_{\mathrm{g} 4}\right) \times \eta_{\mathrm{B}}
\end{aligned}
$$

where:

$\mathrm{C}_{\mathrm{g}}$ - the mean specific heat of exhaust gas from boiler inlet to outlet, $[\mathrm{kJ} /(\mathrm{kg} \mathrm{K})]$,

$\dot{\mathrm{m}}_{\mathrm{g}}$ - the mass flow rate of exhaust gas, $[\mathrm{kg} / \mathrm{h}]$,

$\eta_{B}-$ exhaust gas boiler efficiency considering the radiation loss, [\%].

\section{Formulae of Evaporator}

The exhaust gas temperature entering the preheater is expressed as:

$$
\mathrm{T}_{\mathrm{g} 3}=\mathrm{T}_{\mathrm{sat}}+\mathrm{T}_{\mathrm{pp}}
$$

According to the law of energy conservation, one can obtain:

$$
\begin{gathered}
\dot{\mathrm{m}}_{\mathrm{exh}, \mathrm{B}} \times\left(\mathrm{h}_{\mathrm{sat}}-\mathrm{h}_{\mathrm{sa}}^{\prime}\right)= \\
=\mathrm{C}_{\mathrm{g}} \times \dot{\mathrm{m}}_{\mathrm{g}} \times\left(\mathrm{T}_{\mathrm{g} 2}-\mathrm{T}_{\mathrm{g} 3}\right) \times \eta_{\mathrm{B}}
\end{gathered}
$$

where:

$\mathrm{h}_{\text {sat }}$ - the enthalpy of saturated steam at specific exhaust gas boiler working pressure, $[\mathrm{kJ} / \mathrm{kg}]$,

$\dot{\mathrm{m}}_{\mathrm{exh}, \mathrm{B}}$ - total steam yield of exhaust gas boiler, $[\mathrm{kg} / \mathrm{h}]$.

\section{Formulae of Superheater}

According to the law of conservation of energy, there will be:

$$
\dot{\mathrm{m}}_{\mathrm{sh}} \times\left(\mathrm{h}_{\mathrm{sh}}-\mathrm{h}_{\mathrm{sat}}\right)=\mathrm{C}_{\mathrm{g}} \times \dot{\mathrm{m}}_{\mathrm{g}} \times\left(\mathrm{T}_{\mathrm{g} 1}-\mathrm{T}_{\mathrm{g} 2}\right) \times \eta_{\mathrm{B}}
$$

where:

$\dot{\mathrm{m}}_{\mathrm{sh}}$ - superheated steam yield of exhaust gas boiler, $[\mathrm{kg} / \mathrm{h}]$,

$\mathrm{h}_{\mathrm{sh}}$ - the enthalpy of superheated steam at specific exhaust gas boiler working pressure, $[\mathrm{kJ} / \mathrm{kg}]$.

According to the law of mass conservation, total steam yield $\dot{\mathrm{m}}_{\mathrm{exh}, \mathrm{B}}$ and mass flow rate of hot well pump $\dot{\mathrm{m}}_{\mathrm{hw}}$ can be expressed:

$$
\begin{gathered}
\dot{\mathrm{m}}_{\text {exh,B }}=\dot{\mathrm{m}}_{\text {heating }}+\dot{\mathrm{m}}_{\mathrm{sh}} \\
\dot{\mathrm{m}}_{\mathrm{hw}}=\dot{\mathrm{m}}_{\text {heating }}+\dot{\mathrm{m}}_{\mathrm{sh}}
\end{gathered}
$$

\section{Objective Formulae}

According to the above formulae, total steam yield $\dot{\mathrm{m}}_{\mathrm{exh}, \mathrm{B}}$ of the WHRS, mass flow rate of the saturated water from the boiler $\dot{\mathrm{m}}_{\mathrm{B} 1}$, superheated steam yield $\dot{\mathrm{m}}_{\mathrm{sh}}$, temperature $\mathrm{T}_{\mathrm{g} 2}$ and temperature $\mathrm{T}_{\mathrm{g} 4}$ can be expressed as Eq. (10)-(14):

$$
\begin{gathered}
=\frac{\dot{\mathrm{m}}_{\mathrm{exh}, \mathrm{B}}=}{\mathrm{C}_{\mathrm{g}} \times \dot{\mathrm{m}}_{\mathrm{g}} \times\left(\mathrm{T}_{\mathrm{g} 1}-\mathrm{T}_{\mathrm{g} 3}\right) \times \eta_{\mathrm{B}}+\dot{\mathrm{m}}_{\text {heating }} \times\left(\mathrm{h}_{\mathrm{sh}}-\mathrm{h}_{\mathrm{sat}}^{\prime \prime}\right)} \\
\dot{\mathrm{h}}_{\mathrm{sh}}-\mathrm{h}_{\mathrm{sat}}^{\prime}
\end{gathered}
$$

$$
\begin{gathered}
\mathrm{T}_{\mathrm{g} 2}=\mathrm{T}_{\mathrm{g} 3}+\frac{\dot{\mathrm{m}}_{\text {exh }, \mathrm{B}} \times\left(\mathrm{h}_{\mathrm{sat}}^{\prime \prime}-\mathrm{h}_{\mathrm{sat}}^{\prime}\right)}{\mathrm{C}_{\mathrm{g}} \times \dot{\mathrm{m}}_{\mathrm{g}} \times \eta_{\mathrm{B}}} \\
\mathrm{T}_{\mathrm{g} 4}=\mathrm{T}_{\mathrm{g} 3}-\frac{\left(\dot{\mathrm{m}}_{\text {exh }, \mathrm{B}}+\dot{\mathrm{m}}_{\mathrm{B} 1}\right) \times\left(\mathrm{h}_{\mathrm{sat}}^{\prime}-\mathrm{h}_{\text {pre }}\right)}{\mathrm{C}_{\mathrm{g}} \times \dot{\mathrm{m}}_{\mathrm{g}} \times \eta_{\mathrm{B}}}
\end{gathered}
$$

The power output of the steam turbine $\mathrm{W}_{\mathrm{ST}}$, total power output of the combined turbines $\mathrm{W}_{\mathrm{CT}}$, total work output of the integrated energy system $W$, available energy $\dot{E}_{\mathrm{w}}$, fuel energy (per hour) $\dot{\mathrm{E}}$ can be written as Eq.(15)-(19):

$$
\mathrm{W}_{\mathrm{ST}}=\dot{\mathrm{m}}_{\mathrm{sh}} \times\left(\mathrm{h}_{\mathrm{sh}}-\mathrm{h}_{\text {back }, \mathrm{s}}\right) \times \eta_{\mathrm{s}} \div 3600
$$

where:

$h_{\text {back,s }}$ - the isentropic enthalpy of wet steam at steam turbine outlet, $[\mathrm{kJ} / \mathrm{kg}$,

$\eta_{\mathrm{s}} \quad-$ isentropic efficiency of steam turbine, [\%].

$$
\mathrm{W}_{\mathrm{CT}}=\mathrm{W}_{\mathrm{ST}}+\mathrm{W}_{\mathrm{PT}}
$$

where:

$\mathrm{W}_{\mathrm{PT}}-$ power output of power turbine, $[\mathrm{kW}]$.

$$
\mathrm{W}=\mathrm{W}_{\text {shaft }}+\mathrm{W}_{\mathrm{PT}}
$$

where:

$\mathrm{W}_{\text {shaft }}-$ main engine shaft power, $[\mathrm{kW}]$.

$$
\begin{gathered}
\dot{\mathrm{E}}_{\mathrm{W}}=\mathrm{W} \times 3600 \\
\dot{\mathrm{E}}=\mathrm{W}_{\text {shaft }} \times \mathrm{SFOC} \div 1000 \times \mathrm{LCV}
\end{gathered}
$$

where:

LCV - Low Calorific Value of fuel oil, [kJ/kg].

Thus, the thermal efficiency of the whole WHRS can be expressed as:

$$
\eta_{\text {cycle }}=\frac{\dot{\mathrm{E}}_{\mathrm{W}}}{\dot{\mathrm{E}}}=\frac{\left(\mathrm{W}_{\text {shaft }}+\mathrm{W}_{\mathrm{CT}}\right) \times 3600}{\mathrm{~W}_{\text {shaft }} \times \mathrm{SFOC} \times \mathrm{LCV} / 1000}
$$

The exergy efficiency $\eta_{\mathrm{ex}}$ and payback time $\mathrm{n}$ of the whole WHRS are defined as Eq. (21)-(22):

$$
\eta_{\text {ex }}=\frac{h_{\text {sh }}-h_{\text {back,act }}}{\left(h_{\text {sh }}-h_{\text {hw }}\right)-T_{0} \times\left(S_{\text {sh }}-S_{\text {hw }}\right)}
$$

where:

$\mathrm{h}_{\text {back,act }}-$ the actual enthalpy of wet steam at steam turbine outlet, $[\mathrm{kJ} / \mathrm{kg}]$,

$\mathrm{h}_{\text {back,act }}=\mathrm{h}_{\text {back,s }}+\left(1-\eta_{\mathrm{s}}\right) \times\left(\mathrm{h}_{\text {sh }}-\mathrm{h}_{\text {back,s }}\right)$,

$\mathrm{S}_{\mathrm{hw}}$ - entropy of feed water, $[\mathrm{kJ} /(\mathrm{kg} \mathrm{K})]$,

$\mathrm{S}_{\mathrm{sh}} \quad-$ entropy of superheated steam, [kJ/( $\left.\left.\mathrm{kg} \mathrm{K}\right)\right]$,

$\mathrm{T}_{0} \quad-$ ambient temperature, $[\mathrm{K}]$.

$$
\mathrm{n}=\frac{\lg \frac{\mathrm{A}}{\mathrm{A}-\mathrm{i} \times \mathrm{P}}}{\lg (1+\mathrm{i})}
$$

where:

A - net income per year, [\$/year],

i - annual interest rate, [\%],

$\mathrm{P}-$ cost of Combined Turbines system, [\$].

\section{RESULTS AND DISCUSSION}

Low gas temperature increases the risk of condensed sulfuric acid and low gas velocities increase the risk of soot deposits[3]. Further, appropriate pinch point should be selected. MAN B\&W Diesel recommends the steam pressure be $0.7 \mathrm{MPa}$ 
$\sim 1.0 \mathrm{MPa}$ for a single-pressure steam system, and the high steam pressure $1.0 \mathrm{MPa} \sim 1.1 \mathrm{MPa}$, the low steam pressure $0.4 \mathrm{MPa} \sim 0.5 \mathrm{MPa}$ for a dual-pressure steam system, and the minimum of pinch point is $20^{\circ}$ [4]. To achieve higher steam yield, higher exergy efficiency and higher thermal efficiency, a lower pinch point should be as low as possible on the premise that the minimum is $20^{\circ}$ and $\mathbf{T}_{\mathbf{g} 4}$ is higher than $166^{\circ}$ [6].

Exhaust gas boiler is designed at the continuous service output (CSO). For main engine $9 \mathrm{~K} 98 \mathrm{ME}-\mathrm{C} 7$, the $\mathrm{CSO}$ is $85 \%$ SMCR $(46053 \mathrm{~kW})$, the mass flow rate of exhaust gas is $384600 \mathrm{~kg} / \mathrm{h}$, and the temperature of exhaust gas is $292^{\circ}$. At the initial calculation, the exhaust gas boiler working pressure is selected at $0.7 \mathrm{MPa}$, and the superheated steam temperature is $270^{\circ}$, the pinch point is $27^{\circ}$ to ensure the outlet temperature of the exhaust gas boiler is high than $166^{\circ}$.

All the analysis and discussion are based on ISO conditions (ambient air temperature is $25^{\circ}$, scavenging air coolant temperature is $25^{\circ}$, barometric pressure is $1000 \mathrm{mbar}$ and exhaust gas back pressure at SMCR is $300 \mathrm{~mm}$ WC), the steam turbine back pressure is $6 \mathrm{kPa}$ and feed water temperature is $50^{\circ}$.

\section{Superheated Steam Yield}

The superheated steam yield is shown in Fig. 6. The yield is very low due to the relative low temperature and mass

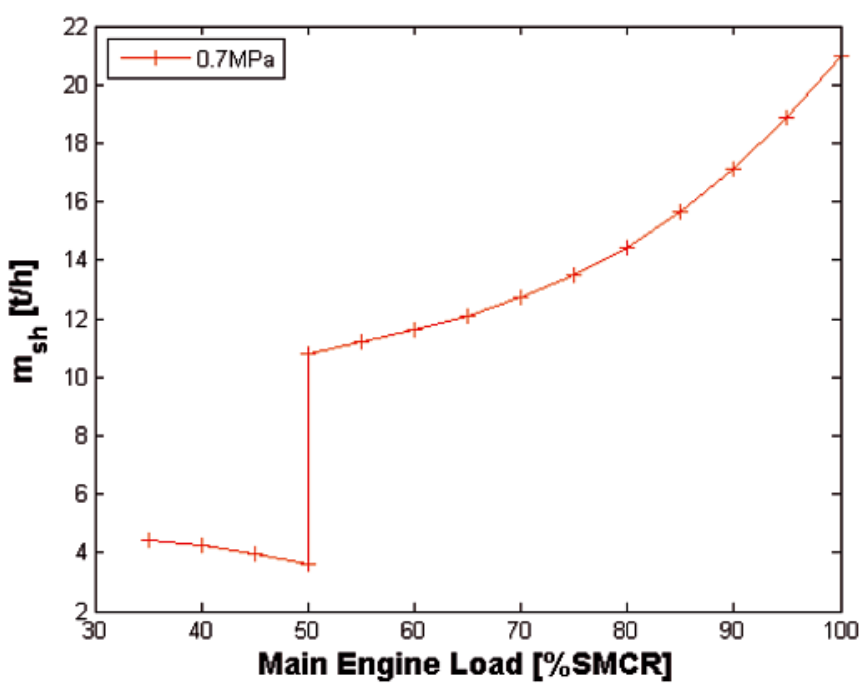

Fig. 6. The variation of superheated steam yield at the specific exhaust gas boiler working pressure - 0.7 MPa with main engine loads for main engine 9K98ME-C7 with Combined Turbines system

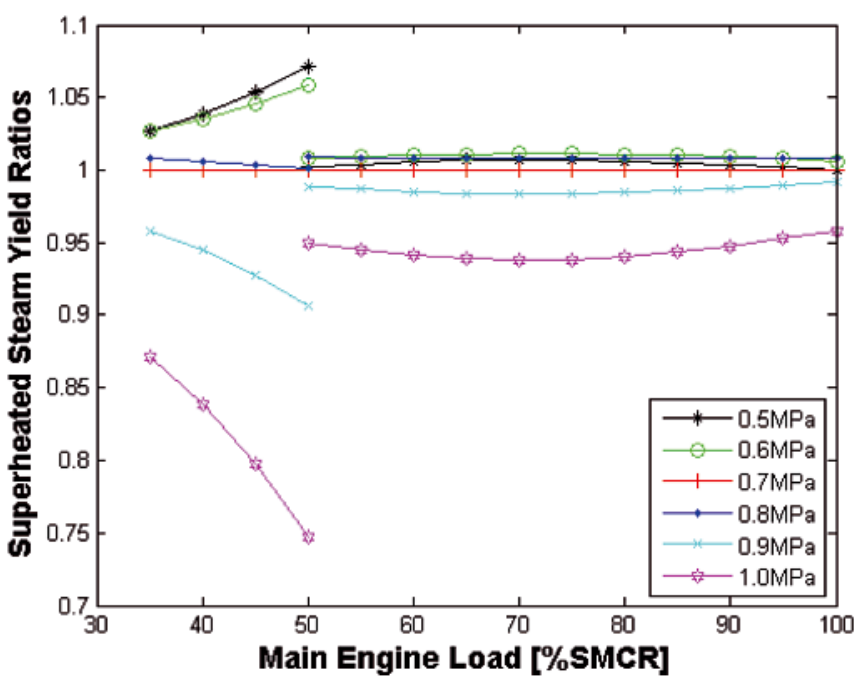

Fig. 7. The variation of ratios of superheated steam yield at other exhaust gas boiler working pressures to the specific pressure - 0.7 MPa with main engine loads for main engine 9K98ME-C7 with Combined Turbines system flow rate when the main engine operates under 50\% SMCR. With main engine loads going up, the yield increases sharply after opening the exhaust gas bypass valve. The variation of ratios of superheated steam yield at other exhaust gas boiler working pressures to the specific pressure - $0.7 \mathrm{MPa}$ with main engine loads is demonstrated in Fig. 7. It is clear that there is not a positive correlation between the superheated steam yield and the exhaust gas boiler pressure, and the maximum of superheated steam yield occurs at the exhaust gas boiler pressure - 0.6 $\mathrm{MPa}$.

\section{Electric Power Yield}

The variation of power output of the steam turbine at the exhaust gas boiler pressure $0.7 \mathrm{MPa}$ with main engine loads is shown in Fig. 8, the variation of power output of the power turbine with main engine loads is shown in Fig. 9. Therefore the electric power yield of the WHRS can be obtained. The variation of ratios of electric power yield at other exhaust gas boiler working pressures to the specific pressure - 0.7 $\mathrm{MPa}$ with main engine loads is shown in Fig. 10. It is clear to see that the most appropriate exhaust gas boiler working pressure is $0.8 \mathrm{MPa}$ for this given main engine due to the maximum electric power yield at full-range engine loads(with pinch point $22^{\circ}$ ).

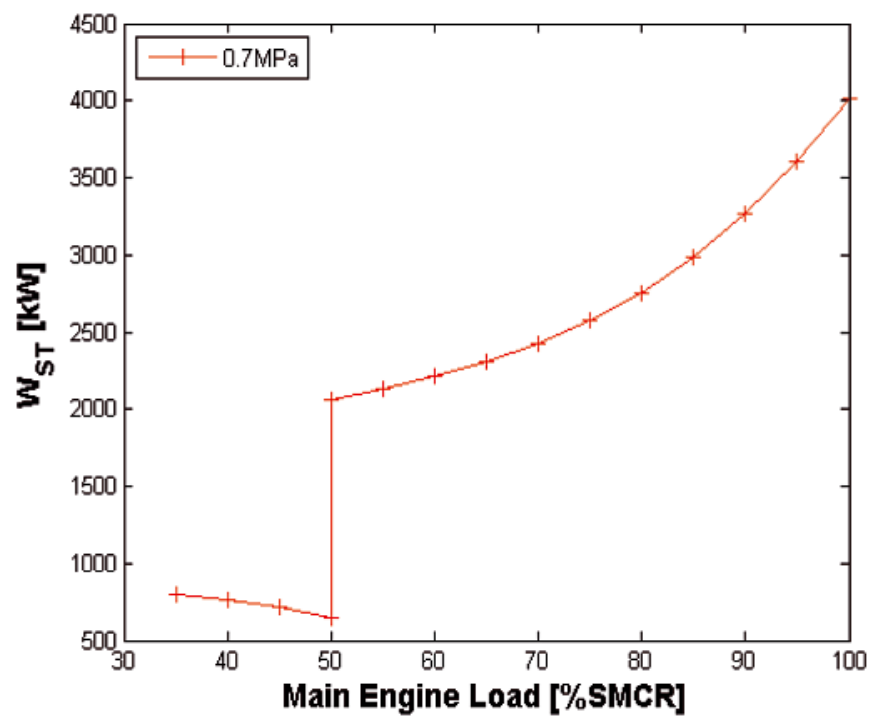

Fig. 8. The variation of power output of the steam turbine at the specific exhaust gas boiler working pressure - $0.7 \mathrm{MPa}$ with main engine loads for main engine 9K98ME-C7 with Combined Turbines system

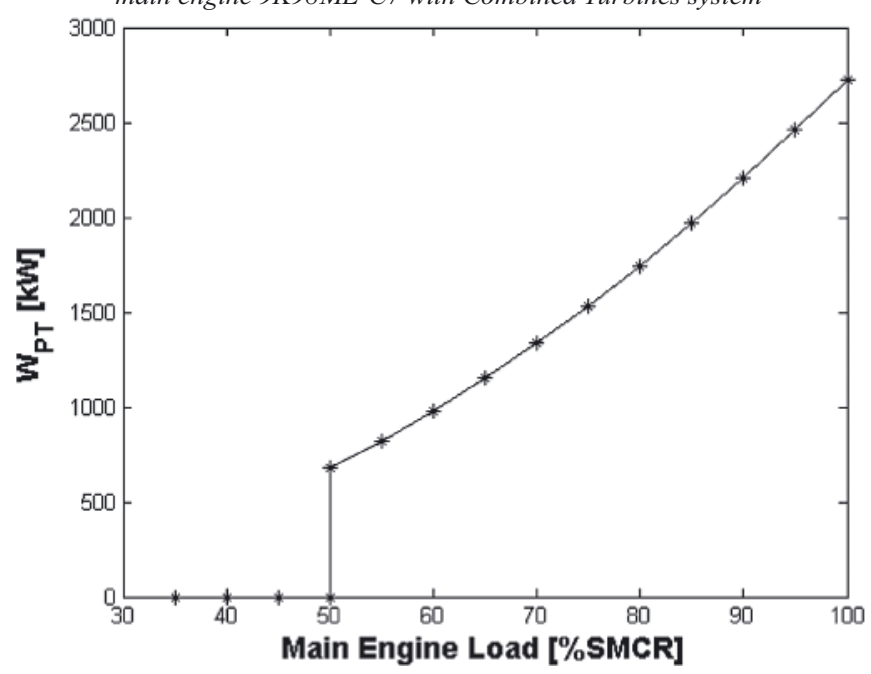

Fig. 9. The variation of power output of the power turbine with main engine loads for main engine $9 K 98 M E-C 7$ with Combined Turbines system 


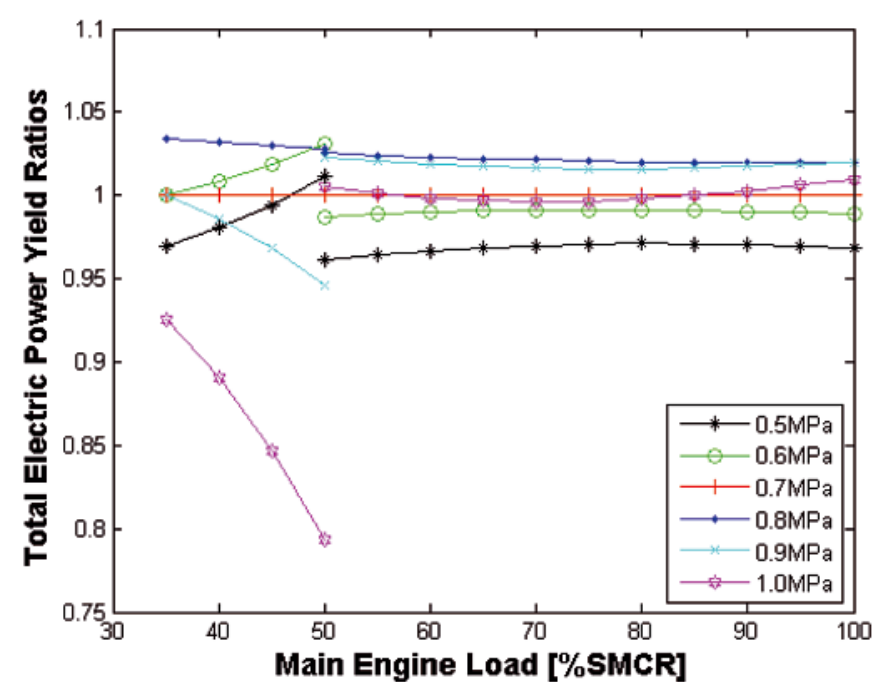

Fig. 10. The variation of ratios of total electric power yield at other exhaust gas boiler working pressures to the specific pressure -0.7MPa with main engine loads for main engine $9 K 98 \mathrm{ME}-\mathrm{C} 7$ with Combined Turbines system

\section{Thermal Efficiency of the WHRS}

The thermal efficiency of the WHRS is shown in Fig. 11. At CSO operating conditions, the shaft power output is about

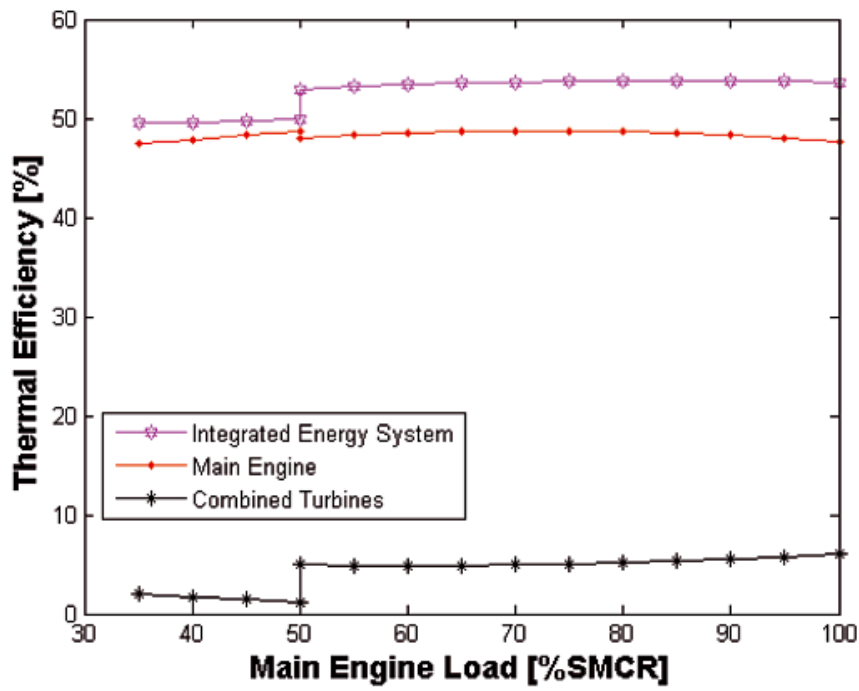

Fig. 11. The variation of ratios of Combined Turbines power output, Main Engine shaft output and Integrated Energy System power output to the total fuel oil energy with main engine loads for main engine 9K98ME-C7 with Combined Turbines system

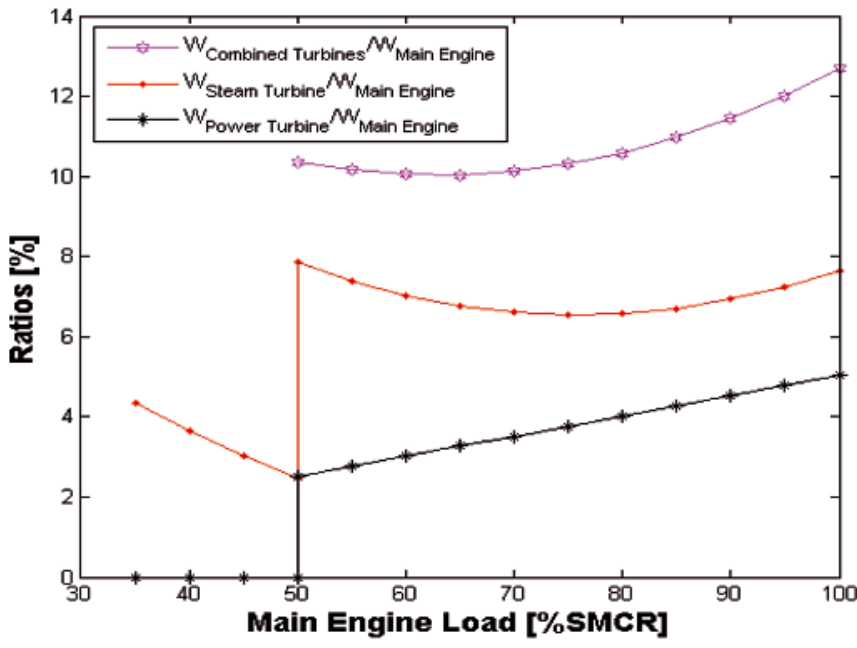

Fig. 12. The variation of ratios of Power Turbine power output, Steam Turbine power output and Combined Turbines power output to Main Engine shaft power with main engine loads for main engine $9 \mathrm{~K} 98 \mathrm{ME}-\mathrm{C} 7$ with Combined Turbines system
$48.5 \%$ relative to the total fuel energy, the total electric power yield of the combined turbines is about $5.3 \%$ relative to the total fuel energy, and the thermal efficiency of the integrated energy system climbs up to $53.8 \%$. The total electric power yield of the combined turbines relative to the shaft power output is shown in Fig. 12. At CSO operating conditions, the relative value is about $11 \%$, the total electric power yield of the combined turbines is about $5066 \mathrm{~kW}$.

\section{Exergy Efficiency of the WHRS}

The variation of exergy efficiency of the WHRS with steam turbine back pressure is shown in Fig. 13. The lower the steam turbine back pressure, the higher the exergy efficiency. The exergy efficiency of the WHRS is about $83.6 \%$ when the exhaust gas boiler pressure is $0.8 \mathrm{MPa}$ and the steam turbine back pressure is $6 \mathrm{kPa}$.

The variation of exergy efficiency of the WHRS with feed water temperature is shown in Fig. 14. Higher feed water temperature increases exergy efficiency of the WHRS.

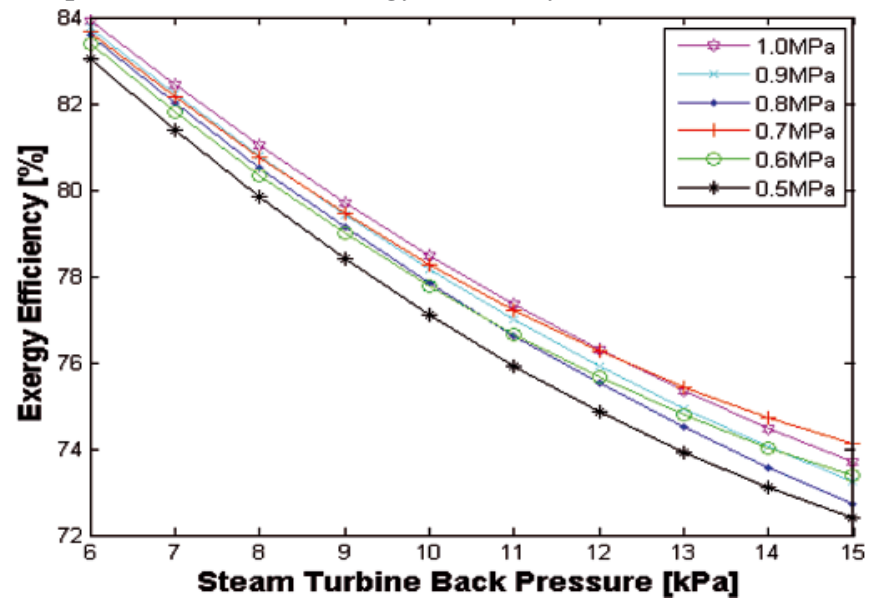

Fig. 13. The variation of exergy efficiency of Combined Turbines system with steam turbine back pressure for main engine $9 \mathrm{~K} 98 \mathrm{ME}-\mathrm{C} 7$ with Combined Turbines system

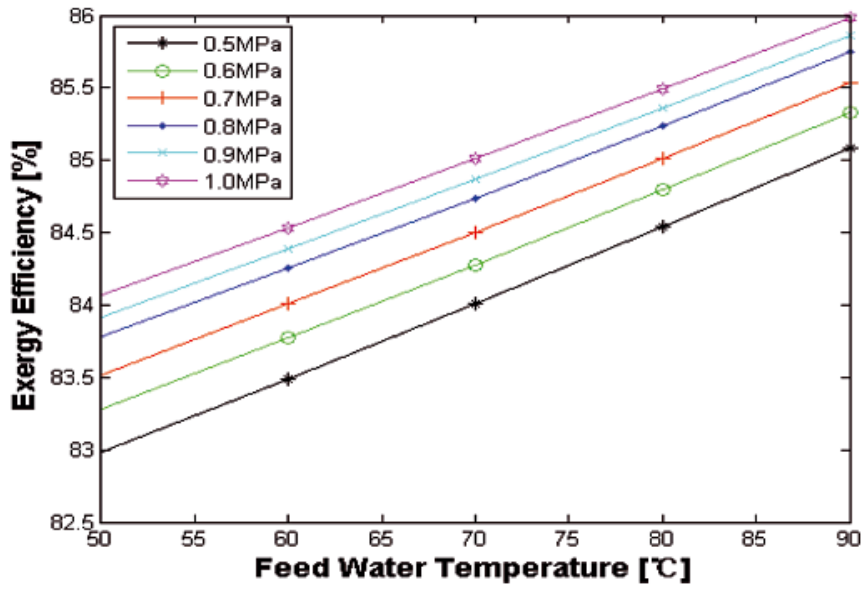

Fig. 14. The variation of exergy efficiency of Combined Turbines system with feed water temperature for main engine $9 K 98 M E-C 7$ with Combined Turbines system

\section{Payback Time}

The container ship studied operates at CSO conditions about 280 days per year. The average number of the refrigerated containers is 400 and each one consumes about $11.4 \mathrm{~kW}$ electricity with $64 \%$ loading rate. The total electricity consumption of the refrigerated containers is $4560 \mathrm{~kW}$, the daily electricity consumption is $2000 \mathrm{~kW}$ and therefore the total electricity consumption onboard is $6560 \mathrm{~kW}$. 
The ship should install $4 \times 2820 \mathrm{~kW}$ diesel generators without the combined turbines. In this case, three diesel generators operate normally while the left as standby. After installing the combined turbines for exhaust gas waste heat recovery, the ship needs $3 \times 2820 \mathrm{~kW}$ diesel generators with one operating normally and two as standby.

The SFOC of the main engine is increased by about $1.8 \%$ with the combined turbines. The SFOC of the main engine is $173.7 \mathrm{~g} /(\mathrm{kW} \cdot \mathrm{h})$ at CSO operating conditions and the SFOC of the diesel-generator engine is $183.8 \mathrm{~g} /(\mathrm{kW} \cdot \mathrm{h})$. The current average fuel oil is $660 \$ / t$ and therefore the annual fuel savings are 4168858 \$. Suppose the cost of the combined turbines is $90000000 \$$, the annual net income ratio is $8 \%$, thus the payback time is about 2.5 years.

The combined turbines system is rather expensive. The application for this system depends on the period of the payback time which is closely related to the price of fuel oil. The higher the worldwide price of fuel oil, the shorter the payback time could be achieved. The variation of payback time with the fuel oil price is shown in Fig. 15. Suppose the price of fuel oil is still high in a long time, to install such combined turbines system studied on large or ultra-large merchant ships will be a great benefit to the ship owners in the long-period service of the ship (normally 25 years).

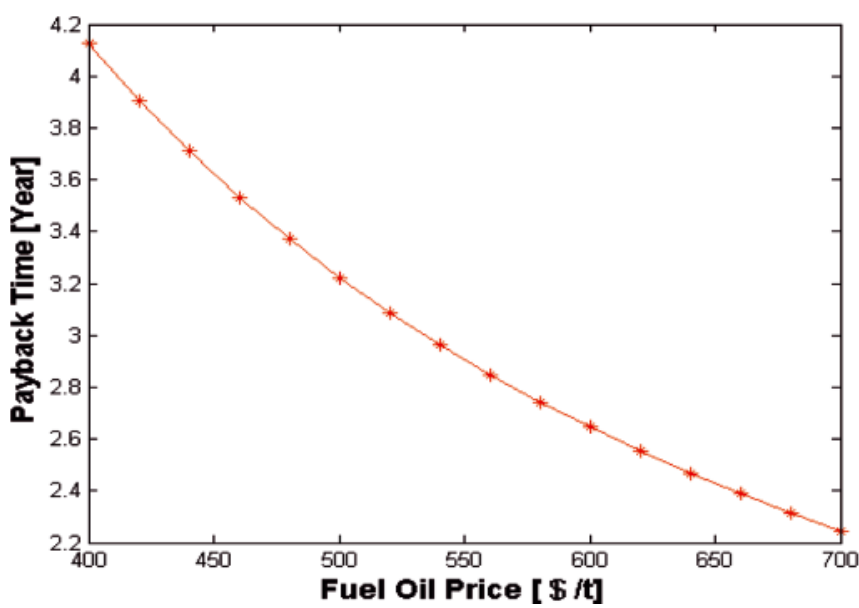

Fig. 15. The variation of payback time of Combined Turbines system with fuel oil price for main engine $9 K 98 \mathrm{ME}-\mathrm{C} 7$ with Combined Turbines system

Tab. 1. Contrast to the Results in Published Literatures

\begin{tabular}{|c|c|c|}
\hline Main Engine Type & $\begin{array}{c}\text { 9K98ME-C7 } \\
{[\mathbf{1 6 ]}}\end{array}$ & 9K98ME-C7 \\
\hline $\begin{array}{c}\text { SMCR kW } \\
\text { Load \%nine (ME) }\end{array}$ & 54180 & 54180 \\
\hline $\begin{array}{c}\text { Main Engine Shaft } \\
\text { Power kW }\end{array}$ & 46053 & 85 \\
\hline $\begin{array}{c}\text { WHR Type } \\
\text { Total Electric Power } \\
\text { Yield kW }\end{array}$ & PTG & $\begin{array}{c}\text { Combined } \\
\text { Turbines }\end{array}$ \\
\hline $\begin{array}{c}\text { In \% of ME Shaft } \\
\text { Power }\end{array}$ & 4.27 & 5066 \\
\hline $\begin{array}{c}\text { ME Thermal } \\
\text { Efficiency \% }\end{array}$ & $48.5 \%$ & $48.5 \%$ \\
\hline $\begin{array}{c}\text { Total Thermal } \\
\text { Efficiency with WHRS } \\
\%\end{array}$ & 50.6 & 53.8 \\
\hline $\begin{array}{c}\text { Increase of Thermal } \\
\text { Efficiency \% }\end{array}$ & 2.1 & 5.3 \\
\hline
\end{tabular}

\section{Contrast to the Results in Published Literatures}

CSSC [16] did the calculation and made a report on the capacities of auxiliary machinery and engine performance data for the same main engine 9K98ME-C7 with PTG for WHR. For a better understand of this problem, a contrast has been shown in Tab. 1.

By contrast, the total electric power yield with Combined Turbines is about 2.6 times as with PTG and the increase of thermal efficiency with Combined Turbines is $3.2 \%$ bigger than with PTG.

\section{CONCLUSION}

Thermodynamic and economic analyses of a WHRSCombined Turbines are performed in this paper.

The most appropriate exhaust gas boiler working pressure is $0.8 \mathrm{MPa}$ for the main engine 9K98ME-C7 with pinch point $22^{\circ}$. At CSO operating conditions, the total electric power yield of the combined turbines is about $5066 \mathrm{~kW}$ and the thermal efficiency of the integrated energy system is nearly $53.8 \%$.

The lower the steam turbine back pressure and the higher the feed water temperature, the higher exergy efficiency of the integrated energy system. The higher the worldwide price of fuel oil, the shorter the payback time could be achieved. Further, operation performance under part load conditions and system arrangement design onboard of such concept WHRS system will be done.

\section{Acknowledgements}

This work is financially supported by the Universities' Natural Science Funding of Jiangsu Province under contract No. 10KJD480001 and the Qing-Lan Project of Jiangsu Province for universities' outstanding youth skeleton teachers under contract No.161220605.

\section{BIBLIOGRAPHY}

1. MAN B\&W Diesel A/S.:Waste Heat Recovery Systems. Copenhagen Denmark, 2007.

2. MAN B\&W Diesel A/S.:Soot Deposits and Fires in Exhaust Gas Boilers. Copenhagen Denmark, 2004.

3. MAN B\&W Diesel A/S.: Waste Heat Recovery System-Green Ship Technology Seminar. p.1-13, Hainan,China, 2010.

4. MAN B\&W Diesel A/S.:Thermo Efficiency System for Reduction of Fuel Consumption and CO2 Emission. Copenhagen Denmark, 2007.

5. WARTSILA Diesel A/S.:Energy savings and environmental benefits via Exhaust Gas Heat Recovery.

6. C.J. Butcher, B.V. Reddy.: The second thermodynamic law analysis of a waste heat recovery based power generation system. International Journal of Heat and Mass Transfer,Vol.50, No.11-12, p.2355-2363, 2007.

7. Dai Y., Wang J., Gao L...: Parametric Optimization and Comparative Study of Organic Rankine Cycle (ORC) for Low Grade Waste Heat Recovery.Energy Conversion and Management, Vol.50, p.576-582, 2009.

8. Yalcin DURMUSOGLU, Tanzer SATIR, Cengiz DENIZ, Alper KILIC.:A Novel Energy Saving and Power Production System Performance Analysis in Marine Power Plant Using Waste Heat. 2009 International Conference on Marine Learning and Applications, p.751-754, 2009.

9. World ShippingCouncil. http://www.worldshipping.org/benefits-of-liner-shipping, 25, January 2010.

10.Review of Marine Transport 2008. United Nations Conference on Trade and Development, ISBN 978-92-1-112758-4, United Nations, 2008. 
11.N.R KRISTIANSEN, H.K. NIELSEN.:Potential for Usage of Thermoelectric Generators on ships. Journal of ELECTRONIC MATERIALS, Vol.39, No.9, p.1746-1749, 2010.

12.J.Yang, F.R.Stabler.:J. Electron.Mater.38, 1344(2009).

13.Liu Shi-Jie, Chen Wu,Cai Zhen-Xiong, Zheng Chao-Yu.: Study on the application of high temperature heat pump to recover waste heat of marine diesel engine. 2009 International Conference on Energy and Environment Technology, Vol. 1, p. 361-364, 2009.

14.MAN B\&W Diesel A/S.: TCS-PTG Savings with Extra Power. Copenhagen Denmark.

15.P.K. Nag, S. De.: Design and operation of a heat recovery system generator with minimum irreversibility.Appl. Therm. Eng.,Vol.17, p.385-391, 1997.
16.China State Shipbuilding Corporation.:Capacities of Auxiliary Machinery and Engine Performance Data for $9 \mathrm{~K} 98 \mathrm{ME}-\mathrm{C} 7$ designed for WHR. China, 2010.

\section{CONTACT WITH THE AUTHORS}

Zheshu Ma, Prof.

Dong Yang, M. Sc.

Qiang Guo, M. Sc.

Department of Power Engineering Jiangsu University of Science and Technology 212003, No.2, Mengxi Road, Zhenjiang City, Jiangsu Province, P.R.China

Tel: 86-13705289269

e-mail: mazheshu@126.com 